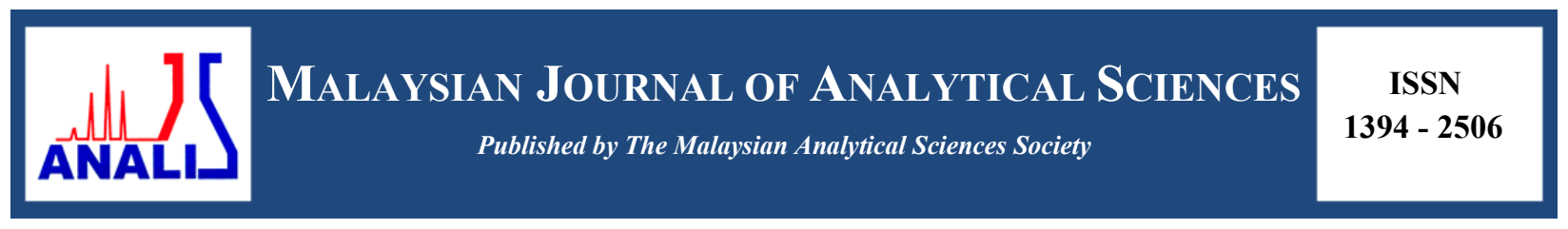

\title{
CHARACTERIZATION, CALCULATION OF CALORIFIC VALUES, AND BIO-OIL PRODUCTION VIA THERMOCHEMICAL PROCESSES OF MUNICIPAL SOLID WASTE IN PERLIS, MALAYSIA
}

\author{
(Pencirian, Pengiraan Nilai - Nilai Kalorifik dan Pengeluaran Bio-Minyak Melalui Proses \\ Termokimia Sisa Pepejal Perbandaran di Perlis, Malaysia) \\ Khairuddin Md Isa ${ }^{1,2 *}$, Farizul Hafiz Kasim ${ }^{2}$, Umi Fazara Md Ali ${ }^{1}$, Radzuwan Ab Rashid ${ }^{3}$ \\ ${ }^{1}$ School of Environmental Engineering, \\ Universiti Malaysia Perlis, P.O Box 77, d/a Pejabat Pos Besar 01007, Kangar, Perlis, Malaysia \\ ${ }^{2}$ Centre of Excellence for Biomass Utilisation, \\ Universiti Malaysia Perlis, Kompleks Pengajian Jejawi 3, 02600 Jejawi, Perlis, Malaysia \\ ${ }^{3}$ Faculty of Languages and Communication, \\ Universiti Sultan Zainal Abidin, 21300 Kuala Nerus, Terengganu, Malaysia \\ *Corresponding author: khairudin@unimap.edu.my
}

Received: 9 January 2017; Accepted: 13 June 2017

\begin{abstract}
Municipal solid wastes (MSW) collected from Padang Siding Landfill, Perlis were segregated and characterized in the laboratory. The main components of MSW found are paper, plastic, glass and large proportion of organic waste. Moisture content was measured for all the components. Paper and yard wastes recorded the highest percentage of $26.7 \%$ and $28.8 \%$, respectively. Thermogravimetric analysis (TGA) shows that the thermal degradation of MSW samples ranged from $200{ }^{\circ} \mathrm{C}$ to $800{ }^{\circ} \mathrm{C}$, indicating fast decomposition occurred at $370{ }^{\circ} \mathrm{C}, 430{ }^{\circ} \mathrm{C}$ and $700{ }^{\circ} \mathrm{C}$. Traditional method shows a lower error compared to the physical method in calculating the calorific values $(\mathrm{CV})$ for MSW. Bio-oil production via fast pyrolysis route gave higher liquid yield of $\sim 35 \%$ with high oxygen content of $\sim 49-53 \%$. Heavy oil recovered from hydrous pyrolysis experiments gave low yield of $\sim 7-13 \%$, however with low oxygen content of $\sim 11-18 \%$.
\end{abstract}

Keywords: Municipal solid waste, thermogravimetric analysis, calorific value, pyrolysis, hydrous pyrolysis

\section{Abstrak}

Sisa pepejal perbandaran (SPP) dikumpulkan dari tapak pelupusan Padang Siding, Perlis. Bahan buangan ini diasingkan dan dikategorikan di dalam makmal. Komponen utama MSW yang ditemui adalah kertas, plastik, kaca dan sebahagian besar sisa organik. Kandungan kelembapan diukur untuk semua komponen di mana kertas dan sisa dari laman telah mencatatkan peratus tertinggi sebanyak $26.7 \%$ dan $28.8 \%$ masing-masing. Analisis termogravimetrik menunjukkan degradasi terma sampel MSW adalah antara $200{ }^{\circ} \mathrm{C}$ hingga $800{ }^{\circ} \mathrm{C}$, menunjukkan penguraian cepat berlaku pada $370{ }^{\circ} \mathrm{C}, 430{ }^{\circ} \mathrm{C}$ dan $700{ }^{\circ} \mathrm{C}$. Kaedah tradisional menunjukkan ralat yang lebih rendah berbanding dengan kaedah fizikal dalam mengira nilai kalorifik untuk SPP. Pengeluaran bio-minyak melalui laluan pirolisis pantas memberikan hasil cecair yang lebih tinggi $\sim 35 \%$ dengan kandungan oksigen yang tinggi $\sim 49-53 \%$. Minyak berat diperoleh daripada eksperimen pirolisis berair memberikan hasil yang rendah $\sim 7-13 \%$, walau bagaimanapun dengan kandungan oksigen yang rendah $\sim 11-18 \%$.

Kata kunci: Sisa pepejal perbandaran, analisa termogravimetrik, nilai kalorifik, pirolisis, pirolisis berair 


\section{Khairuddin et al: CHARACTERIZATION, CALCULATION OF CALORIFIC VALUES, AND BIO-OIL PRODUCTION VIA THERMOCHEMICAL PROCESSES OF MUNICIPAL SOLID WASTE IN PERLIS, MALAYSIA}

\section{Introduction}

Municipal solid waste (MSW), also known as urban solid waste, is a type of waste that predominantly comes from household waste (domestic waste) with a small portion of commercial waste collected by municipality of a particular area. Generally, the solid waste is defined as the household's refusal and non-hazardous solid waste from industrial, commercial and institutional establishments, such as hospitals, market and yard wastes, and street sweepings [1]. MSW is a heterogeneous material and its physical composition is dependent on socio-economic level and climatic conditions [2].

Perlis Indera Kayangan is the smallest state in Malaysia which is located at the northern part of the Peninsular Malaysia. Its population is 227,025 as of 2010 . The increase in population and industrial activities in Perlis has resulted in serious environmental problems including air quality deterioration, water and land pollutions. The amount of solid wastes generated in Perlis is approximately 221 tonnes/day [3]. The most popular disposal practice for MSW is landfilling. Landfilling is a universal solution that provides ultimate waste disposal and can be implemented easily. However, the setback of this approach is that it requires a large piece of land and does not employ the concepts of reduction and conversion of MSW. The MSW disposal in Perlis is located at Padang Siding landfill with an area approximately 50.876 hectare. Landfills face the problems of overfilling, overflowing of leachates leading to pollution of water resources, and uncontrolled dust emissions adversely affecting the human environment [4].

In order to justify the feasibility of energy recovery for the use of renewable energy, it is very important to determine the calorific value (CV) of MSW. Bomb calorimeter can be used for calorimetric measurement in which combustion is conducted under conditions of constant volume. Other important methods are physical composition and traditional methods where the energy content can be calculated using physical and proximate analysis, respectively.

One option of utilizing the MSW is energy recovery through various processes, such as combustion, pyrolysis, liquefaction and refuse-derived fuel [5]. Several researchers have pyrolyzed biomass residue to produce bio-oil under certain conditions [6-8]. Bio-oil is dark brown liquid which has a high heating value that can be used as fuels in boiler, diesel engines for power generation, or upgraded to produce fuels and bulk chemicals. However, direct usage of bio-oil as conventional fuels may present some difficulties due to high viscosity, poor heating value, corrosiveness and instability. The comparison of pyrolysis and hydrous pyrolysis of MSW has not been done in earlier studies and this study attempts to fill in the gap. The comparison is beneficial for engineers and policy makers to design an alternative solution for MSW.

A large portion of the waste has significant energy potential which can be utilized. The energy recovered can also reduce emissions that would otherwise be produced by other energy systems, such as fossil fuel thermal power plants [9]. An important criterion for the success of waste management plan is the accurate data on the quality and quantity of the waste generation. With this data, proper management strategies can be planned and put into actions. The data can also be used to predict the future trends of the quantity and quality of the MSW. This allows the authorities to take anticipating measures to manage MSW generated properly [10].

In order to justify the feasibility of energy recovery for the use of renewable energy, it is very important to determine the calorific value (CV) of MSW. Bomb calorimeter can be used for calorimetric measurement in which combustion is conducted under the condition of constant volume. Other important methods are physical composition and traditional methods where the energy content can be calculated using physical and proximate analysis, respectively.

In Perlis, there is less data available on the potential of MSW to be used as energy sources. To fill in the gap, this study was conducted to segregate and characterize the main components of MSW in the state. The energy contents of MSW generated were calculated. The production of bio-oil was performed via thermochemical conversion processes to investigate its potential to be used as a renewable energy. 


\section{Sample preparation}

\section{Materials and Methods}

The solid waste samples were collected at Padang Siding landfill in Arau, Perlis. The sampling was carried out randomly at 5 different locations within the $0.12 \mathrm{~km}^{2}$ landfill area of $0.6 \mathrm{~m}$ depth. These samples were brought back to the laboratory for analysis. The manual segregation process was conducted to calculate the MSW's components. After the completion of segregation, all the samples were mixed, washed (with water) and oven dried at $105{ }^{\circ} \mathrm{C}$ for 12 hours to eliminate external moisture. The samples (except glass) were shredded and sieved to obtain uniform size less than $1.5 \mathrm{~mm}$ for further experimental works. This sample was used for TGA analysis and pyrolysis experiments.

\section{Moisture-content determination}

The collected samples were oven-dried at $105^{\circ} \mathrm{C}$ for 5 hours to measure moisture-content. All the moisture content values used in this research were based on the wet basis, unless otherwise stated. The percentage of moisture content was calculated as follow:

$$
\text { Moisture (\%) }=\left[\frac{\text { Wet weight-dryweight }}{\text { Wet weight }}\right] \times 100 \%
$$

\section{Thermogravimetric analysis}

The thermogravimetric analysis was carried out by using a TGA/DSC 1 Mettler Toledo. The weight loss and the rate of weight loss were recorded continuously under dynamic conditions, as functions of time or temperature, in the range of 25 to $900{ }^{\circ} \mathrm{C}$. Purified nitrogen gas was used for the pyrolysis with a flow rate of $150 \mathrm{ml} / \mathrm{min}$. The heating rate of $20^{\circ} \mathrm{C} / \mathrm{min}$ was selected for this test. The temperature was increased to the setting value of $900{ }^{\circ} \mathrm{C}$ at the pre-selected heating rate and it was kept constant at this value until steady conditions were obtained.

\section{Proximate analysis}

Proximate analysis was performed according to ASTM D2974 [11] using the thermogravimetric analyzer (TGA/DSC 1, Mettler Toledo) for determination of moisture, volatile matter, fixed carbon and ash in MSW. The experiment was performed under inert nitrogen gas and purified air with a constant flow rate of $150 \mathrm{ml} / \mathrm{min}$ and the heating rate of $20{ }^{\circ} \mathrm{C}$. The samples were weighed directly into the alumina crucible and the temperature was kept at isothermal for 0.5 minutes until a steady condition was obtained before ramping to the desired temperature [12]. The experiments were replicated at least twice to obtain reproducibility.

\section{Calorific value (CV)}

The calorific values (CVs) of the samples were determined by using a bomb calorimeter (Model: C2000 basic, IKA co, Germany). The calculation was also made according to the model developed by Khan and Abu Ghrarah [13] as reported by Abu-Qudais and Abu-Qdais [5].

$$
\mathrm{E}=23[\mathrm{~F}+3.6(\mathrm{PA})]+160(\mathrm{PL})
$$

where $\mathrm{E}$ is the energy content of MSW (Btu/lb), PL is the percentage of plastic by weight, $\mathrm{F}$ is the percentage of food waste by weight and PA is the percentage of paper waste by weight.

For comparison, a traditional model reported by Abu-Qudais and Abu Qdais [5] had also been employed as follows:

$$
\mathrm{E}(\mathrm{Kcal} / \mathrm{kg})=45 \mathrm{~B}-6 \mathrm{~W}
$$

where B is the combustible volatile matter in MSW (\%) and W is the water percentage weight on dry basis (\%).

\section{CHNO analyses}

The elemental analyses of the oils were determined using Thermo Electron FlashEA 1112 elemental analyser. Vanadium pentoxide (2-3 mg) was used to determine the Sulphur content and the amount of Sulphur found was too small and negligible for the calculation of this research. 


\section{Khairuddin et al: CHARACTERIZATION, CALCULATION OF CALORIFIC VALUES, AND BIO-OIL PRODUCTION VIA THERMOCHEMICAL PROCESSES OF MUNICIPAL SOLID WASTE IN PERLIS, MALAYSIA}

\section{Pyrolysis experimental procedure}

Fast pyrolysis was conducted in a fixed-bed reactor as in our previous study [7]. The experimental device consisted of a tube reactor with a volume of $250 \mathrm{~cm}^{3}$, equipped with a K-type thermocouple, an electric heater, a nitrogen cylinder, a cold trap, water bath and product effluent. The condensation temperature was set at $0{ }^{\circ} \mathrm{C}$ for all experiments. The amounts of sample used in all experiments were $5 \mathrm{mg}$ per run. The bio-oil yield was collected from oil collector and weighed to calculate the percentage. For all experiments, whenever the pyrolysis temperature was reached, it was immediately cooled down to $100{ }^{\circ} \mathrm{C}$ within 4 minutes. Experiments were repeated 5 times to ensure the reproducibility of the results.

Nitrogen flow rate and condensation temperature were kept constant at $100 \mathrm{~cm}^{3} / \mathrm{min}$ and $0{ }^{\circ} \mathrm{C}$, respectively. The pyrolysis experiments were conducted using fixed bed pyrolyser at pyrolysis temperature of $470{ }^{\circ} \mathrm{C}$, particle size of $0.60 \mathrm{~mm}$, holding time at 1 minute. Experiments were repeated 5 times to ensure the reproducibility of the results.

\section{Hydrous experimental procedure}

Hydrous experiments were conducted using a Parr 4740 series stainless steel $(75 \mathrm{ml}$ cylindrical) pressure vessel at pre-set temperatures $\left(380,420\right.$ and $\left.480{ }^{\circ} \mathrm{C}\right)$ for 1 hours. After sealing the vessel and attaching the pressure gauge, it was purged 10 times with nitrogen gas to remove the air, and then 2 bar of nitrogen gas was introduced to provide an inert atmosphere. The reactor was heated in a fluidised sand bath. Temperature was monitored by an additional K-type thermocouple which was connected to a computer and recorded every $10 \mathrm{~s}$. The reacted product washing procedure had been reported in the previous study [14]. Hydrous pyrolysis was also conducted at 380,420 and 480 ${ }^{\circ} \mathrm{C}$ with sample to water mass ratio of $1: 6$, using $75 \mathrm{ml}$ reactor for 1 hour. The pressures recorded for these experiments were in the range of $280-300$ bar.

\section{Waste segregation and moisture content}

\section{Results and Discussion}

Table 1 shows the average compositions after the segregation process. Plastic and glass were the highest proportion in the samples collected with approximately $46 \%$. Similarly, papers contributed approximately $21 \%$, ranked as the third largest component. The other smallest components were polystyrene, yard wastes and wood with 1.4\%, 3.5\% and $8.0 \%$, respectively. Food waste consists of approximately $12 \%$, as such, it can be inferred that the management of organic waste has not been properly done.

Table 1. Characterization of MSW from Padang Siding landfill

\begin{tabular}{lcccccccc}
\hline Sample & $\begin{array}{c}\text { Food Waste } \\
\mathbf{( \% )}\end{array}$ & $\begin{array}{c}\text { Paper } \\
\mathbf{( \% )}\end{array}$ & $\begin{array}{c}\text { Plastic } \\
\mathbf{( \% )}\end{array}$ & $\begin{array}{c}\text { Polystyrene } \\
\mathbf{( \% )}\end{array}$ & $\begin{array}{c}\text { Rubber } \\
\mathbf{( \% )}\end{array}$ & $\begin{array}{c}\text { Yard waste } \\
\mathbf{( \% )}\end{array}$ & $\begin{array}{c}\text { Glass } \\
\mathbf{( \% )}\end{array}$ & $\begin{array}{c}\text { Wood } \\
\mathbf{( \% )}\end{array}$ \\
\hline 1 & 37.80 & 1.50 & 13.90 & 1.20 & 24.70 & 6.40 & 0.00 & 14.50 \\
2 & 2.80 & 4.00 & 15.40 & 2.20 & 11.30 & 7.80 & 46.20 & 10.20 \\
3 & 12.50 & 16.80 & 14.20 & 0.60 & 6.90 & 0.00 & 43.90 & 5.20 \\
4 & 5.30 & 24.70 & 48.40 & 2.70 & 0.00 & 0.00 & 11.50 & 7.40 \\
5 & 0.00 & 56.20 & 12.40 & 0.30 & 0.00 & 3.40 & 24.90 & 2.90 \\
Average & 11.68 & 20.64 & 20.86 & 1.40 & 8.58 & 3.52 & 25.3 & 8.04 \\
\hline
\end{tabular}

Note: Mud and gravel had been removed from the samples

Moisture contents of the MSW components are summarized in Table 2. As expected, paper, polystyrene, and yard wastes had the highest proportion with $26.7 \%, 25.0 \%$, and $28.8 \%$, respectively. Rubber had the lowest percentage of moisture with $10.2 \%$. The high moisture content is normally attributed to the climate of the area. Perlis is a tropical climate state with a large amount of rainfall obtained throughout the year. The annual rainfall is approximately $2,700 \mathrm{~mm}$ and may increase up to $6,000 \mathrm{~mm}$ in the catchment region. On top of this, the average air humidity in Perlis is above $80 \%$ [15]. 
Table 2. Moisture content of MSW components from Padang Siding, Perlis Landfill

\begin{tabular}{lccc}
\hline Waste Components & $\begin{array}{c}\text { Wet weight } \\
(\mathbf{k g})\end{array}$ & $\begin{array}{c}\text { Dry weight } \\
(\mathbf{k g})\end{array}$ & $\begin{array}{c}\text { Moisture Content } \\
(\mathbf{\%})\end{array}$ \\
\hline Food waste & 0.780 & 0.682 & 12.6 \\
Paper & 0.030 & 0.022 & 26.7 \\
Plastic & 0.286 & 0.238 & 16.8 \\
Polystyrene & 0.024 & 0.018 & 25.0 \\
Rubber & 0.510 & 0.458 & 10.2 \\
Yard waste & 0.132 & 0.094 & 28.8 \\
Wood & 0.300 & 0.268 & 10.7 \\
\hline
\end{tabular}

\section{Proximate and TGA analysis}

Proximate analysis was carried out in order to determine the moisture content (dry basis), volatile matter content, fixed carbon content and ash content in the waste samples. The analysis was conducted for the combination of yard wastes, plastic, paper, polystyrene, wood and rubber. Table 3 tabulates the proximate analysis for 5 samples collected from Padang Siding Landfill. Volatile matter had 68\% in average and offered high percentage of condensable gas. The thermochemical conversion method is the best option as condensable gas is promising in amount. The proximate analysis conducted in previous studies set in Penang, Malaysia, shows that the investigated MSW comprised of $44.66 \%$ of moisture content, $44.55 \%$ of volatile matter, $8.56 \%$ of ash content and $2.23 \%$ of fixed carbon content [16]. Typically, based on the proximate percentages range for moisture content in residential, MSW is about $15 \%$ to $40 \%$, volatile matter comprises approximately $40 \%$ to $60 \%$ and the range for fixed carbon is from $4 \%$ to $15 \%$ [17].

Table 3. Proximate analysis of MSW from Padang Siding landfilla

\begin{tabular}{lcccccc}
\hline \multirow{2}{*}{ Variable (wt. \%) } & \multicolumn{5}{c}{ Sample } & \multirow{2}{*}{ Average } \\
\cline { 2 - 6 } & $\mathbf{1}$ & $\mathbf{2}$ & $\mathbf{3}$ & $\mathbf{4}$ & $\mathbf{5}$ & \\
\hline Moisture content & 7 & 10 & 5 & 7 & 5 & 7 \\
Volatile matter & 53 & 71 & 68 & 71 & 79 & 68 \\
Fixed carbon & 10 & 7 & 10 & 10 & 2 & 8 \\
Ash content & 30 & 12 & 17 & 12 & 14 & 17 \\
\hline
\end{tabular}

Note: ${ }^{a}$ dry basis

The TG analysis is usually used for thermal characterization, calculation of the pyrolysis conversion and evaluation of reactivity and kinetic parameters [7]. In this research, the purpose of TG analysis was to look into the degradation profile for MSW. Figure 1 shows the thermal decomposition of MSW. The initial curve indicates that there was moisture loss of up to $105{ }^{\circ} \mathrm{C}$. The decomposition was gradually increased starting from $200{ }^{\circ} \mathrm{C}$ until it had a fast decomposition reaching $350{ }^{\circ} \mathrm{C}$. Up to $400{ }^{\circ} \mathrm{C}$, the remaining residue was $40 \%$ and about $60 \%$ was decomposed. The decomposition produced approximately 15 to $17 \%$ of ash content. This result is in agreement with the waste compositions described earlier. The carbon residues ranged between 10 to $17 \%$ pose significant carbon deposition during refinery upgrading (e.g. catalytic cracking), whereas the values above $20 \%$ are considered problematic. The decomposition trend was observed to be influenced by the waste compositions, such as paper, wood and plastic. For each TG experiment, the weight loss of MSW as a function of temperature cannot be simulated by considering a single decomposition reaction [18]. The remaining others slowly degraded over $350{ }^{\circ} \mathrm{C}$ until $800^{\circ} \mathrm{C}$. They are 4 zones indicated as A, B, C and D in thermogravimetric curve and this is presented clearly in the DTG curve. 


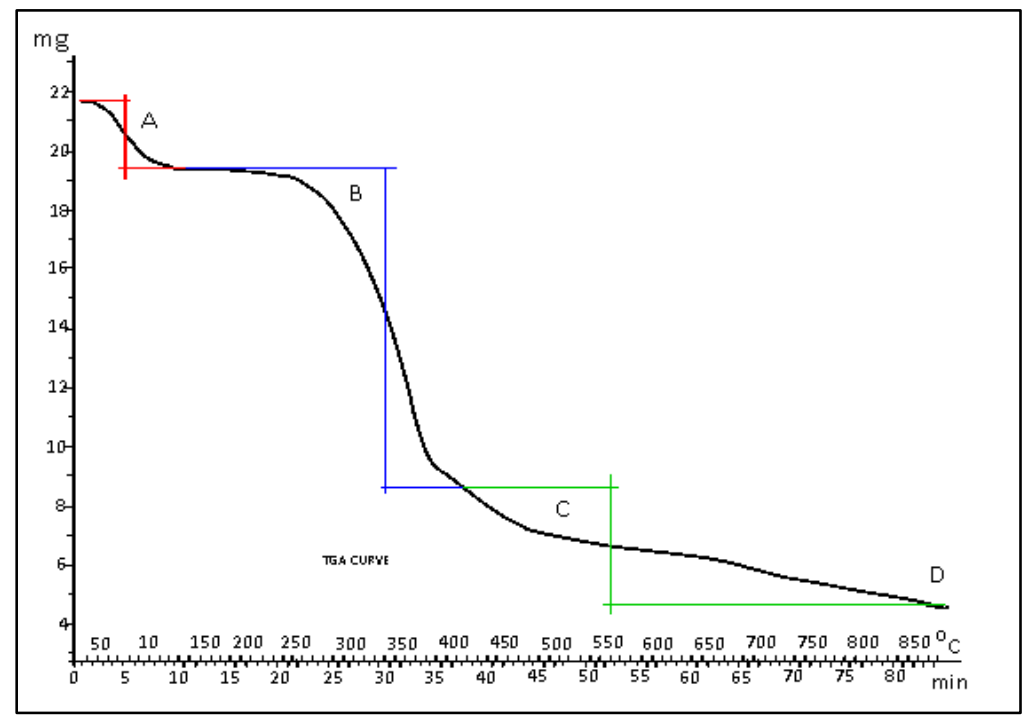

Figure 1. TGA curves for MSW samples

Figure 2 shows the DTG evolution profiles for MSW samples. Zone A indicated moisture loss curve while Zones $\mathrm{B}, \mathrm{C}$ and $\mathrm{D}$ were attributed to the waste compositions. The fast decomposition occurred at three regions which were at $350{ }^{\circ} \mathrm{C}, 430{ }^{\circ} \mathrm{C}$ and $700{ }^{\circ} \mathrm{C}$. The fast decomposition at zone B was caused by the degradation of materials, such as wood and yard wastes. Based on the DTG evolution profiles, material at zone B started to decompose at temperature ranging from $200{ }^{\circ} \mathrm{C}$ to about $400{ }^{\circ} \mathrm{C}$, with $\mathrm{T}_{\max }$ at $350{ }^{\circ} \mathrm{C}$. It was followed by the degradation of plastic and the fast decomposition was shown at $\mathrm{C}$. Zone $\mathrm{C}$ recorded the burn-out temperature starting from $400{ }^{\circ} \mathrm{C}$ and ended at $480{ }^{\circ} \mathrm{C}$. The more stable materials, such as rubber, gradually degraded and recorded fast decomposition at $700{ }^{\circ} \mathrm{C}$. Small percentage of rubber contributed to the small peak at $700{ }^{\circ} \mathrm{C}$. The burn-out temperature occurred at $600{ }^{\circ} \mathrm{C}$ with $\mathrm{T}_{\max }$ at $750{ }^{\circ} \mathrm{C}$. The differences in the DTG profiles showed the difference in the complexity of MSW components. Shen and Qinlei reveal three steps in their previous study due to the emission and combustion of the volatiles with the char combustion [19].

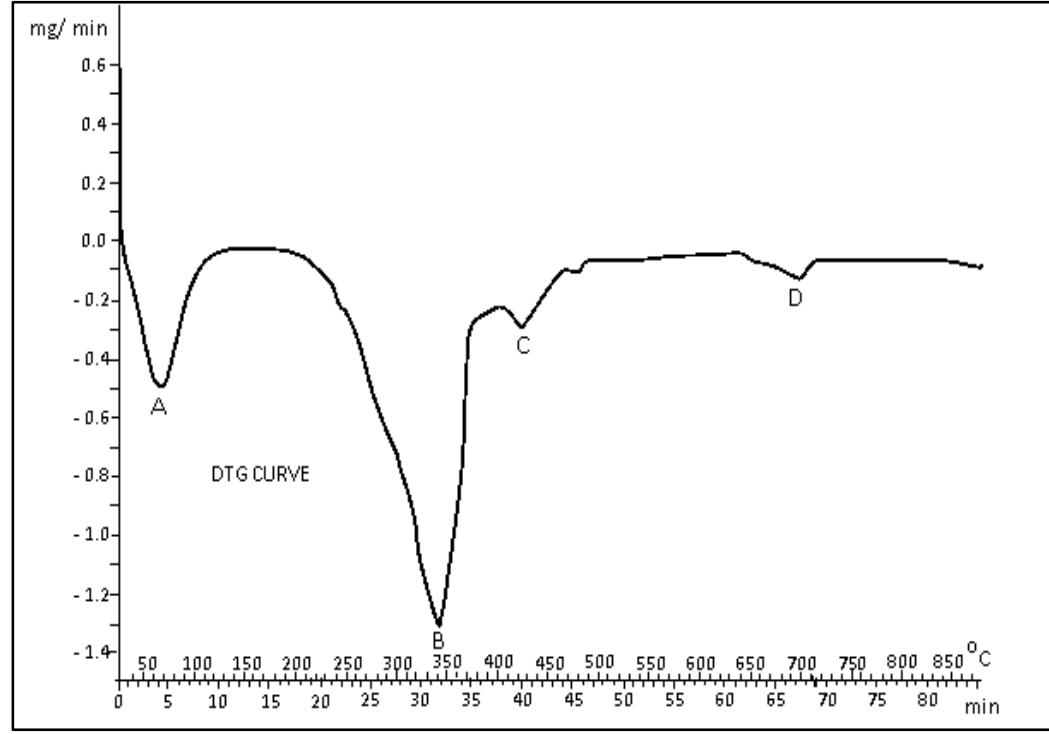

Figure 2. DTG curves for MSW samples 


\section{Calorific values (CVs)}

Table 4 shows the calorific values of MSW by using bomb calorimeter, calculations employing physical composition and proximate analysis techniques. The calorific values ranging from 2200 to $4500 \mathrm{kcal} / \mathrm{kg}$ were obtained for all samples by using bomb calorimeter. Sample No. 4 had the highest value while sample No.1 recorded the lowest. Kathirvale et al. reported that the calorific values of the Malaysian MSW ranged between 1500 and $2600 \mathrm{kcal} / \mathrm{kg}$ [20]. The CVs calculated employing physical composition gave values ranging from 1601 to $5550 \mathrm{kcal} / \mathrm{kg}$ while proximate analysis technique gave values ranging from 2343 to $4000 \mathrm{kcal} / \mathrm{kg}$. In physical composition, sample No. 4 gave the highest value with $5550 \mathrm{kcal} / \mathrm{kg}$. This was attributed to the composition of paper and plastic and it is in agreement with PL/PA ratio as reported by Abu-Qudais and Abu-Qdais [5]. Traditional method shows a lower error compared to the physical method. The result from traditional method analysis is useful in calculating CVs in MSW study compared to the physical method.

Table 4. Comparison of CVs determined by different methods

\begin{tabular}{lccc}
\hline \multirow{2}{*}{$\begin{array}{l}\text { Waste } \\
\text { Sample }\end{array}$} & \multicolumn{3}{c}{ Calorific Value (kcal/kg) } \\
\cline { 2 - 4 } & Bomb Calorimeter & Physical Composition & Traditional Method \\
\hline 1 & 2200 & 1802 & 2343 \\
2 & 2500 & 1601 & 3135 \\
3 & 3451 & 2212 & 3030 \\
4 & 4500 & 5550 & 4000 \\
5 & 3480 & 3717 & 3525 \\
\hline
\end{tabular}

\section{Thermochemical processes}

The pyrolysis experiments were conducted using fixed bed pyrolyser at pyrolysis temperature of $470{ }^{\circ} \mathrm{C}$ and the biooil produced was $\sim 35 \%$. The hydrous pyrolysis were conducted at 380,420 and $480{ }^{\circ} \mathrm{C}$ to investigate the effect of temperature on product distribution (Figure 3). The high gas yield obtained at $480{ }^{\circ} \mathrm{C}(42 \%)$ had resulted in the decrease of liquid products due to the further thermal decomposition [21]. As decomposition to form gas occurred when the temperature had increased to $480{ }^{\circ} \mathrm{C}$, the oil plus water yield decreased to $42 \%$. Of this, $6 \%$ was recovered as heavy oil while approximately $10-12 \%$ of heavy oil was recovered at 380 and $420{ }^{\circ} \mathrm{C}$.

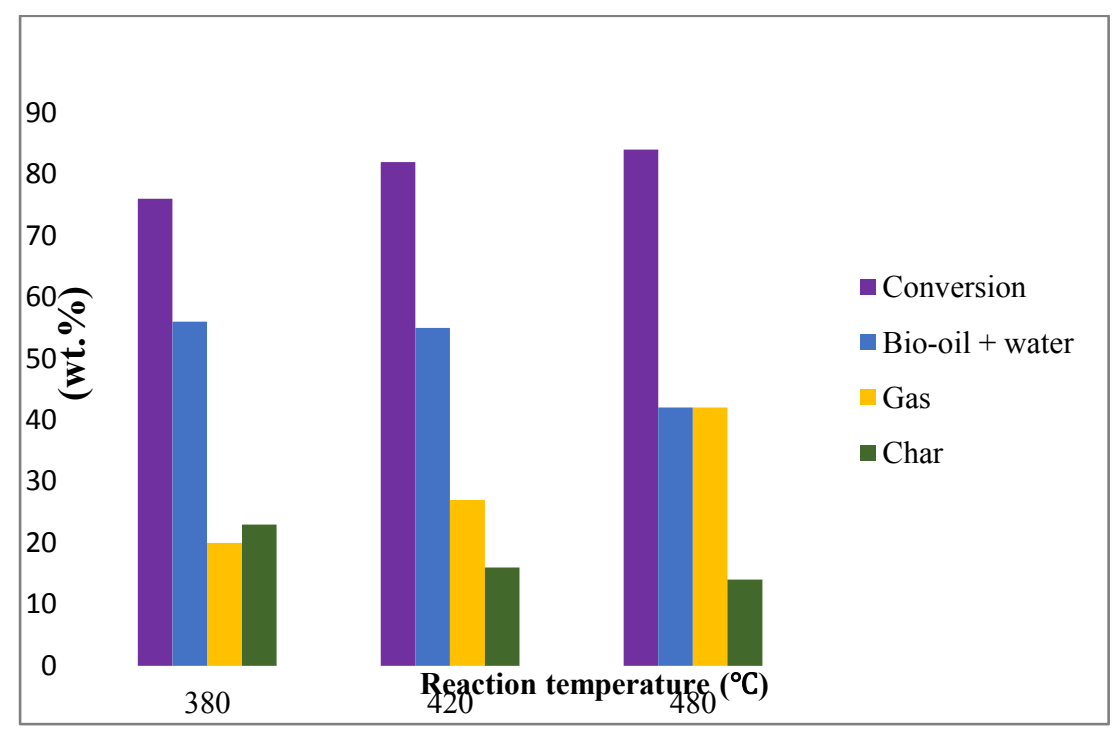

Figure 3. Effect of reaction temperature on product yields using MSW sample to water mass ratio of 1:6 for 1 hour 


\section{Khairuddin et al: CHARACTERIZATION, CALCULATION OF CALORIFIC VALUES, AND BIO-OIL PRODUCTION VIA THERMOCHEMICAL PROCESSES OF MUNICIPAL SOLID WASTE IN PERLIS, MALAYSIA}

Table 5 presents the elemental compositions of the bio-oils and heavy oils obtained from pyrolysis and hydrous experiments. An increase in temperature gave low oxygen contents $(\sim 11 \%)$ for heavy oil from hydrous pyrolysis and bio-oils obtained from direct fast pyrolysis had high oxygen content $(\sim 49-53 \%)$.

Table 5. Elemental analyses of bio-oils and heavy oils from pyrolysis and hydrous pyrolysis experiments

\begin{tabular}{llcccc}
\hline Runs & Samples & $\mathbf{C ~ ( \% )}$ & $\mathbf{H ~ ( \% )}$ & $\mathbf{N}(\%)$ & $* \mathbf{O}(\mathbf{\%})$ \\
\hline \multirow{2}{*}{ Pyrolysis } & Bio-oil 1 & 42.0 & 7.0 & 0.3 & 50.7 \\
& Bio-oil 2 & 43.0 & 6.9 & 0.4 & 49.7 \\
& Bio-oil 3 & 40.0 & 7.0 & 0.3 & 52.7 \\
Hydrous pyrolysis & Heavy oil $\left(380{ }^{\circ} \mathrm{C}\right)$ & 74.0 & 6.8 & 0.6 & 18.6 \\
& Heavy oil $\left(420{ }^{\circ} \mathrm{C}\right)$ & 77.0 & 7.1 & 0.6 & 15.3 \\
& Heavy oil $\left(480{ }^{\circ} \mathrm{C}\right)$ & 81.0 & 7.3 & 0.5 & 11.2 \\
\hline
\end{tabular}

*Oxygen by difference

\section{Conclusion}

The MSW in Perlis mainly consists of plastic and paper followed by food waste, wood, yard waste and polystyrene. Referring to the wide range of wastes, the thermogravimetric analysis displays a broad range of degradation temperature starting from $200{ }^{\circ} \mathrm{C}$ to $800{ }^{\circ} \mathrm{C}$. DTG curves illustrate the fast decompositions that occurred at $350{ }^{\circ} \mathrm{C}$, $430{ }^{\circ} \mathrm{C}$ and $700{ }^{\circ} \mathrm{C}$ which represent different waste components. For each TG experiment, the weight loss of MSW due to temperature cannot be simulated by considering a single decomposition reaction. CVs calculation employing traditional method gave a lower error compared to the physical method. The physical composition method could be employed for MSW CVs calculation if the MSW compositions are influenced by ratio of plastic to paper. Bio-oil production via fast pyrolysis route gave higher liquid yield of $\sim 35 \%$ with high oxygen content of $\sim 49-53 \%$. Heavy oil recovered from hydrous pyrolysis experiments gave low yield of $\sim 7-12 \%$, however with low oxygen content of $\sim 11-18 \%$.

\section{Acknowledgement}

The researchers thank Universiti Malaysia Perlis for funding this work.

\section{References}

1. Hannan, M. A., Arebey, M., Basri, H. and Begum, R. A. (2010). Intelligent solid waste bin monitoring and management system. Australian Journal of Basic and Applied Sciences, 4(10): 5314 - 5319.

2. Cheng, H. and Hu, Y. (2010). Municipal solid waste (MSW) as a renewable source of energy: Current and future practices in China. Bioresource Technology, 101(11): 3816 - 3824.

3. Johari, A., Alkali, H., Hasyim, H., Ahmed, S. and Mat, R. (2014). Municipal solid waste management and potential revenue from recycling in Malaysia. Modern Applied Science, 8(4): 37 - 49.

4. Syed, A. K. S. A., Abidin, H. Z., Sulaiman, M. R., Khoo, K. H. and Ali, H. (2008). Combustion characteristics of Malaysian municipal solid waste and predictions of air flow in a rotary kiln incinerator. Journal of Material Cycles Waste Management, 10: 116 - 123.

5. Abu-Qudais, M. and Abu-Qdais, H. A. (2000). Energy content of municipal solid waste in Jordan and its potential utilization. Energy Conversion \& Management, 41(9), 983 - 991.

6. Isa, K. M., Ying, L. J., Saad, S. A., Kasim, F. H. and Rahim, M. A. A. (2016). Pyrolysis of oil palm fronds in a fixed bed reactor and optimisation of bio-oil using Box-Behnken Design. Journal of Advanced Research in Fluid Mechanics and Thermal Sciences, 27(1), $12-18$.

7. Isa, K. M., Daud, S., Hamidin, N., Ismail, K. and Kasim, F. K. (2011). Thermogravimetric analysis and the optimisation of bio-oil yield from fixed-bed pyrolysis of rice husk using response surface methodology (RSM). Industrial Crops and Products, 33(2): 481 - 487. 
8. Chen, X., Chen, Y., Yang, H., Chen, W., Wang, X. and Chen, H. (2017). Fast pyrolysis of cotton stalk biomass using calcium oxide, Bioresource Technology, 233: 15 - 20.

9. Liamsanguan, C. and Gheewala, S. H. (2007). Environmental assessment of energy production from municipal solid waste incineration. The International Journal of Life Cycle Assessment, 12(7): $529-536$.

10. Kathirvale, S. Yunus, M. N. M., Sopian, K., Samsuddin, A. H. and Rakmi, A.R. (2002). Comprehensive characteristic of the municipal solid waste generated in Kuala Lumpur. In Proceedings of the Regional Symposium on Environment and Natural Resources, Kuala Lumpur, Malaysia: pp. 359 - 368.

11. Annual Book of ASTM Standards, D2974 volume 5.05. The American Society for Testing and Material (ASTM), Philadelphia, PA.

12. Ismail, K., Zakaria, Z. and Ishak, M. A. M. (2005). Proceeding of $22^{\text {nd }}$, International Pittsburgh Coal Conference, Pittsburgh, USA.

13. Khan, A. M. Z. and Abu Ghrarah, Z. H. (1991). New approach for estimating energy content of municipal solid waste. Journal Environmental Engineering, 117(3), 376 - 380.

14. Isa, Md. K., Snape, C. E., Uguna, C. and Meredith, W. (2015). High conversions of miscanthus using sub- and supercritical water above $400{ }^{\circ} \mathrm{C}$. Journal of Analytical and Applied Pyrolysis, 113: 646 - 654 .

15. Hamatschek, E., Tee, S. S. and Faulstich, M. (2010). Current practice of municipal solid waste management in Malaysia and the potential for waste-to-energy implementation. ISWA World Congress, $1-13$.

16. Chai, S. P. and Zakaria, R. (2006). Investigation of combustion characteristic of municipal solid waste from Penang State Malaysia. $4^{\text {th }}$ International Conference on Combustion, Incineration/Pyrolysis and Emission Control: Waste to Wealth, Kyoto, Japan.

17. Tchobanoglous, G., Theisen, H. and Vigil, A. S. (1993). Integrated solid waste management, engineering principles and management issues. Mc Graw-Hill, New York.

18. Garcia, A. N., Marcilla, A. and ont, R. (1995). Thermogravimetric kinetic study of the pyrolysis of municipal solid waste. Thermochimica Acta, 254: 277 - 304.

19. Shen, B. and Qinlei. (2006). Study on MSW catalytic combustion by TGA. Energy Conversion \& Management, 47(11-12): $1429-1437$.

20. Kathirvale, S., Yunus, M. N. M., Sopian, K. and Samsuddin, A. H. (2003). Energy potential from municipal solid waste in Malaysia. Renewable Energy, 29(4): 559 - 567.

21. Onsri, K., Prasassarakich, P. and Ngamprasertsith, S. (2010). Co-liquefaction of coal and used tire in supercritical water. Energy Power Engineering, 2: 95 - 102. 